Pesq. Vet. Bras. 37(8):790-796, agosto 2017

DOI: $10.1590 / \mathrm{S} 0100-736 \mathrm{X} 2017000800002$

\title{
Clinical, blood gas and biochemical profile of diarrheic dairy calves fed starter concentrate containing citrus pulp as a replacement for $\operatorname{corn}^{1}$
}

\author{
Marcelo Cezar Soares², Marília Ribeiro de Paula², Giovana Simão Slanzon², Flávia \\ Hermelina Rocha ${ }^{2}$, Gerson Barreto Mourão ${ }^{2}$ and Carla Maris Machado Bittar ${ }^{2 *}$
}

\begin{abstract}
Soares M.C., Paula M.R., Slanzon G.S., Rocha F.H., Mourão G.B. \& Bittar C.M.M. 2017. Clinical, blood gas and biochemical profile of diarrheic dairy calves fed starter concentrate containing citrus pulp as a replacement for corn. Pesquisa Veterinária Brasileira 37(8):790-796. Departamento de Zootecnia, Escola Superior de Agricultura Luiz de Queiroz, Universidade de São Paulo, Avenida Pádua Dias 11, Piracicaba, SP 13418-900, Brazil. E-mail: carlabittar@usp.br

The objective of this study was to evaluate clinical signs, gas analysis, and metabolic effects of diarrhea in milk-fed calves consuming starter feed containing citrus pulp (CP) as a replacement for corn. Twenty-four newborn Holstein male calves were distributed into treatments according to starter composition: (1) $0 \% \mathrm{CP}$, (2) 32\% CP, (3) 64\% CP, on dry matter basis. The calves were housed in individual hutches, with free access to water and concentrate, and received $4 \mathrm{~L} / \mathrm{d}$ of milk replacer. After diarrhea diagnosis, evaluations of fecal score, score of clinical signs and measurement of physiological parameters were performed three times a day during 3-d. Blood samples were collected for electrolytes, blood gases, and plasma biochemical analysis. Starter feed composition had no negative effect $(\mathrm{P}>0.05)$ on fecal score, characteristics of diarrheic stools and on the aggravation of diarrhea clinical signs. Biochemical, blood gases and electrolytes changes, as a function of starter composition, did not resulted $(\mathrm{P}>0.05)$ in dehydration, acidosis, or other metabolic disturbance animals. Total lactate and D-lactate plasma concentrations were higher for calves on control and $64 \% \mathrm{CP}$, and L-lactate was highest for the $64 \% \mathrm{CP}$; however, calves showed no signs of metabolic acidosis. Thermal comfort indexes influenced clinical and physiological parameters $(\mathrm{P}<0.05)$. Citrus pulp may replace corn in starter composition without prejudice to intestinal health or metabolism of young diarrheic calves.
\end{abstract}

INDEX TERMS: Clinical profile, blood gas, biochemical profile, diarrhea, citrus pulp, replacement for corn, byproducts, dairy calves, metabolic disorders, starter feed.

RESUMO.- [Perfis clínico de gás sanguíneo e bioquímico de bezerros leiteiros diarreicos alimentados com concentrado inicial contendo polpa cítrica como substituto de milho.] 0 objetivo desse estudo foi o de avaliar os sinais clínicos, análise de gases e os efeitos metabólicos da diarreia em bezerros em aleitamento, consumindo concentrado inicial contendo polpa cítrica (PC) como substituto de milho. Vinte e quatro bezerros recém-nascidos da raça

\footnotetext{
${ }^{1}$ Received on October 26, 2015.

Accepted for publication on September 12, 2016.

${ }^{2}$ Departamento de Zootecnia, Escola Superior de Agricultura Luiz de Queiroz, Universidade de São Paulo, Av. Pádua Dias 11, Piracicaba, SP 13418-900, Brazil. *Corresponding author: carlabittar@usp.br
}

Holandesa foram distribuídos, de acordo com a composição do concentrado, nos seguintes tratamentos: (1) $0 \%$ PC, (2) 32\% PC, (3) 64\% PC, na matéria seca. Os bezerros foram alojados em abrigos individuais, com acesso livre a água e concentrado, e receberam $4 \mathrm{~L} / \mathrm{d}$ de sucedâneo lácteo. Após o diagnóstico de diarreia, avaliações de escore fecal, sinais clínicos e medidas de parâmetros fisiológicos foram realizadas três vezes ao dia durante 3 -d. Amostras de sangue foram colhidas para análise de eletrólitos, hemogasometria e metabólitos plasmáticos. A composição do concentrado não afetou o escore fecal, as características das fezes diarreicas, ou o agravamento dos sinais clínicos da diarreia $(\mathrm{P}>0,05)$. Alterações nos parâmetros plasmáticos, de hemogasometria ou de eletrólitos, em função da com- 
posição do concentrado, não resultaram em desidratação, acidose ou outro distúrbio metabólico nos bezerros diarreicos $(\mathrm{P}>0,05)$. As concentrações de lactato total e D-lactato foram superiores para bezerros alimentados com concentrado sem inclusão de polpa ou com 64\% de inclusão, enquanto a concentração de L-lactato foi superior somente para aqueles consumindo concentrado com $64 \%$ de PC. No entanto, os bezerros não apresentaram sinais de acidose metabólica. Os índices de conforto térmico influenciaram os parâmetros clínicos e fisiológicos $(\mathrm{P}<0,05)$. A polpa cítrica pode substituir o milho na composição de concentrados para bezerros sem prejudicar a saúde intestinal ou o metabolismo de bezerros jovens acometidos por diarreia.

TERMOS DE INDEXAÇÃO: Perfil clínico, gás sanguíneo, perfil bioquímico, diarreia, polpa cítrica, substituição de milho, co-produtos, bezerros leiteiros, distúrbios metabólicos, concentrado inicial.

\section{INTRODUCTION}

Feeding concentrate to dairy calves is required for rumen development, allowing weaning and maintenance of adequate performance thereafter (Quigley et al. 1991). Starter composition is usually based on corn as the main energy source, with very low inclusion of alternative ingredients. However, the availability and lower costs of some by-products allow the formulation of starters with the same energy values, though the literature lacks information about levels of inclusion and possible effects on diarrhea occurrence. During the last years, the use of citrus pulp as an alternative to reduce feeding costs has been increased. Even though there are several studies with the inclusion of citrus pulp for adult animals (Bampidis \& Robinson 2006, Nussio et al. 2002), few studies were conducted with its effects on dairy calves performance. Comparing citrus pulp inclusion rates of $0,15,30$, and $40 \%$ is calves diets, Wing (1982) observed low intake and acceptability problems for diets with more than $15 \%$ of citrus pulp for calves under 60 days of age. However, acceptability increased as animals aged and, after 60 days of age, levels of $30 \%$ of DM may be fed. Indeed, Harris \& Staples (1989) recommend up to $10 \%$ of total DM of citrus pulp for animals younger than 60 days. Williams et al. (1987) reported an increase in starter intake and average daily gain of milk-fed calves receiving a mixture of citrus pulp and beet pulp instead of barley. Schalch et al. (2001) found no differences among treatments for average daily gain, dry matter intake, feed conversion or rumen development when evaluated the replacing of corn grain with $0,15,30$ or $45 \%$ citrus pulp in the starter of milk-fed calves.

Young dairy calves are unable to digest pectin, which may be a problem when citrus pulp is included in the starter because of its effects in the intestine and possibility of diarrhea, since according to Schalch et al. (2001) it has a laxative effect. Diarrhea is the main death cause in young calves and results in decreased performance and increased rearing costs. Even though most of the time diarrhea cases are related to inadequate transfer of passive immunity and cleanliness issues (Botteon et al. 2008), it may also occurs because of inadequate nutrition. On the other hand, the replacement of a source of starch by a source of pectin, may benefit rumen health, mainly regarding to the decreased lactate production from fermentation and consequent rumen acidosis (Bampidis \& Robinson 2006)

Thus, the objective of this study was to verify whether the replacement of corn with citrus pulp in the starter concentrate of calves might cause negative effects for calves such as dehydration, acid-basic imbalance and acidosis during diarrhea occurrence.

\section{MATERIALS AND METHODS}

The study was conducted at Experimental Calf Section of the Animal Science Department of the College of Agriculture "Luiz de Queiroz", Piracicaba, São Paulo, Brazil, from December 2011 to March 2012. All procedures performed involving animals were approved by the Ethics Committee on Animal Experimentation (CEUA/ESALQ). Twenty-four newborn Holstein male calves were fed $4 \mathrm{~L} / \mathrm{d}$ of colostrum, divided into twice a day feedings, until the second day of life. Animals were housed in individual shelters distributed in a grassy field; their average initial age was $14 \pm 5$ days and the average birth weight was $39 \pm 3.1 \mathrm{~kg}$. The shelters were provided with feeders and a bucket with water to guarantee ad libitum access. The calves were distributed into blocks, according to birth data and weight, and assigned to one of the following treatments, according to citrus pulp (CP) replacement for corn: $0 \% \mathrm{CP}(0 \% \mathrm{CP}$ and $64 \%$ corn), 32\% CP (32\% CP and $32 \%$ corn) and 64\%CP (64\% CP and 0\% corn). Calves were fed $4 \mathrm{~L} / \mathrm{d}$ of milk replacer (Sprayfo Violeta ${ }^{\circledR}$ 20CP:16EE, 12.5\% solids, Sloten of Brazil Ltd., Santos, SP, Brazil) that were divided into two meals (7h00 and 17h00). The starter concentrate, formulated according to the experimental treatment (Table 1), was provided daily, and the daily intake was monitored through the weight of orts. The weaning was performed abruptly at the eighth week of life when the experimental period ended.

The calves were healthy at the beginning of the study. However, because the trial was conducted during the summer, it was expected that all calves would have at least one diarrhea episode during the milk-feeding period. To determine the diarrhea occurrence, evaluations of fecal score of all animals were performed every morning according to Larson et al. (1977) and were classified according to the fluidity: (1) when normal and solid; (2) when feces had a pasty consistency but a generally healthy aspect; (3) when feces had an aqueous consistency and were considered to be diarrhea; (4) when feces had a fluid consistency. Diarrhea cases were considered when the fecal score was $\geq 3$. Calves that were considered to have diarrhea were monitored for a three-day period to evaluate the color, consistency and fecal components as described by the same authors. During this period, rectal temperature, heart rate, and respiratory rate were measured at $7 \mathrm{~h} 00,12 \mathrm{~h} 00$, and $19 \mathrm{~h} 00$. In addition, the clinical sign scores were evaluated in diarrheal calves according to methodology adapted from Kasari \& Naylor (1986). The score for each variable was added to obtain a minimum score of zero for healthy calves and a maximum score of 12 for debilitated calves presenting with severe clinical signals.

Environment temperature, air humidity, and wind speed were measured since thermal comfort indexes interfere with the physiological parameters. To verify the peak of heat stress for the animals, the humidity and temperature index (HTI) was calculated by using the equation described by Thom (1959): HTI $=(0.8 \times \mathrm{T}$ $+(\mathrm{AH} / 100) \times(\mathrm{T}-14.4)+46.4)$, where $\mathrm{T}=$ ambient temperature $\left({ }^{\circ} \mathrm{C}\right)$ and $\mathrm{AH}=$ air humidity $(\%)$.

Also, during the three days after the diarrhea diagnosis, blood samples were collected two hours after the milk replacer morning feeding by using tubes with sodium fluoride as an antiglicolytic 
and ethylenediamine tetraacetic acid (EDTA) as an anticoagulant, or tubes containing sodium heparin, according to the analysis. Immediately after the blood collection, the samples in the sodium heparin tubes were evaluated for glucose, hematocrit, blood gas, and concentrations of sodium $(\mathrm{Na})$, potassium $(\mathrm{K})$, chloride $(\mathrm{Cl})$, blood $\mathrm{pH}$, carbon dioxide pressure $\left(\mathrm{PCO}_{2}\right)$, plasma urea nitrogen (PUN), hemoglobin $(\mathrm{Hb})$, bicarbonate $\left(\mathrm{HCO}_{3}^{-}\right)$, base excess $\left(\mathrm{BE}_{\mathrm{ecf}}\right)$, and anion gap by using a portable blood analyzer i-Stat ${ }^{\circledR}$ with the EC8+ cartridge (Abbot Point of Care Inc., Princeton, New Jersey, USA). Samples were centrifuged at 2,000xg for 20 minutes at a temperature of $4^{\circ} \mathrm{C}$ (Universal 320R, Hettich, Tuttlinger, German), and plasma was frozen for further analyses. Commercial enzymatic kits (Labtest Diagnóstica S.A., Lagoa Santa, MG, Brazil) were used for the determination of plasma glucose (Ref. 85), total protein (Ref. 99), albumin (Ref.19), and L-lactate (Ref. 138). For the determination of $\beta$-hydroxybutyrate a commercial enzymatic kit (RANDOX Laboratories, Life Sciences Ltd., Crumlin, UK) was utilized. The analyses of total plasma lactate concentration were performed based on the methodology described by Pryce (1969). The determination of D-lactate was obtained by calculating the difference between the results of total plasma lactate $(\mathrm{mg} / \mathrm{dL})$ and plasma L-lactate $(\mathrm{mg} / \mathrm{dL})$.

The experimental design was a randomized block that considered the birth weight and date of the animal. For binomial variables, generalized linear models were utilized with the logit link function (GLIMMIX). Data of blood parameters and the evaluations of clinical signs were analyzed in a factorial design by using the procedure MIXED of SAS (version 9.0, SAS Institute Inc., Cary, NC). To compare the effect of the means, the Student t-test was utilized, where the means were estimated through the minimum square method with a significance level of $5 \%$.

\section{RESULTS}

The average environment temperature during the experimental period was $24.2^{\circ} \mathrm{C}\left(\mathrm{T}_{\min } 14.7^{\circ} \mathrm{C}\right.$ and $\left.\mathrm{T}_{\max } 36.8^{\circ} \mathrm{C}\right)$ and the average temperature and humidity index (THI) was 73.9 (THI $_{\min } 71.9$ and $\mathrm{THI}_{\max }$ 76.1). The replacement of corn by citrus pulp in the concentrate did not affect $(\mathrm{P}>0.05)$ the fecal score of the animals during the liquid-feeding phase (Fig.1). The clinical score and physiological parameters were also not affected by the inclusion of citrus pulp in the starter concentrate and there was no effect of the evaluation day on clinical score and physiological parameters. However, there was a difference $(\mathrm{P}<0.0001)$ among time of the day $(7 \mathrm{~h} 00,12 \mathrm{~h} 00$, and $19 \mathrm{~h} 00)$ during which the animals were submitted to the evaluations (Table 2; Fig.2). Hematocrit was not affected $(\mathrm{P}<0.05)$ by the composition of the

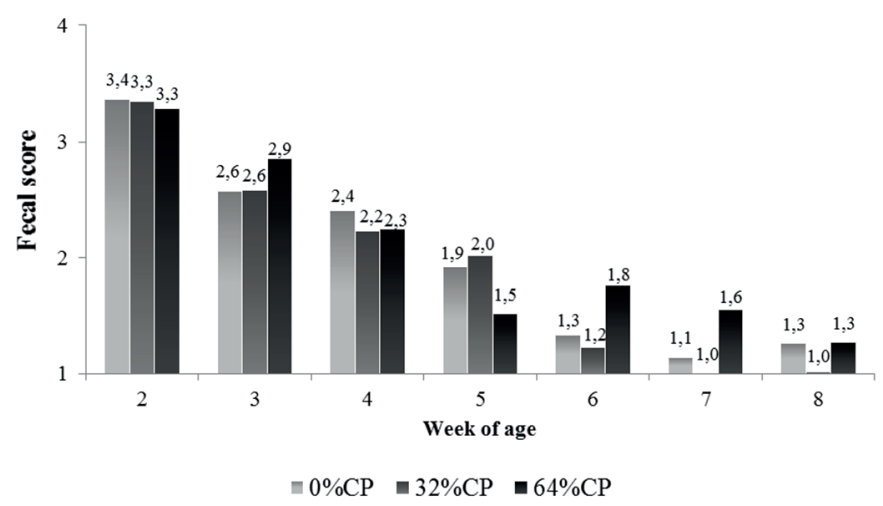

Fig.1. Fecal scores of calves fed starter feed containing citrus pulp.
Table 1. Ingredients e chemical composition of starter concentrate with different levels of citrus pulp as a replacement for corn

\begin{tabular}{|c|c|c|c|}
\hline \multirow[t]{2}{*}{ Ingredients, \% DM } & \multicolumn{3}{|c|}{ Treatments $^{\dagger}$} \\
\hline & $0 \% \mathrm{CP}$ & $32 \% \mathrm{CP}$ & $64 \% \mathrm{CP}$ \\
\hline Ground corn & 64.0 & 32.0 & 0.0 \\
\hline Citrus pulp & 0.0 & 32.0 & 64.0 \\
\hline Soybean meal & 26.0 & 28.0 & 28.0 \\
\hline Wheat meal & 6.0 & 5.5 & 7.0 \\
\hline Limestone & 3.0 & 1.5 & 0.0 \\
\hline Minerals and vitamins ${ }^{\ddagger}$ & 1.0 & 1.0 & 1.0 \\
\hline \multicolumn{4}{|l|}{ Chemical composition } \\
\hline Dry matter (\%) & 89.9 & 90.5 & 90.9 \\
\hline Ashes (\% DM) & 5.88 & 7.3 & 9.4 \\
\hline Crude protein (\% DM) & 20.6 & 20.7 & 19.5 \\
\hline Ether extract (\% DM) & 3.4 & 3.0 & 2.8 \\
\hline Neutral Detergent Fiber (\% DM) & 13.4 & 17.7 & 21.7 \\
\hline Acid Detergent Fiber (\% DM) & 7.5 & 11.2 & 17.3 \\
\hline Lignin (\% DM) & 0.66 & 1.30 & 1.87 \\
\hline Non-fiber Carbohydrates (\% DM) & 56.7 & 51.3 & 46.6 \\
\hline Total Digestible Nutrients (\% DM) & 82.72 & 77.20 & 73.61 \\
\hline Calcium $(\mathrm{g} / \mathrm{kg})^{\S}$ & 1.40 & 1.43 & 1.49 \\
\hline Phosphorus $(\mathrm{g} / \mathrm{kg})^{\S}$ & 0.41 & 0.41 & 0.36 \\
\hline Metabolizable Energy (Mcal/kg DM) & 2.94 & 2.97 & 2.96 \\
\hline Gain net energy (Mcal/kg MS) ${ }^{\S}$ & 1.36 & 1.37 & 1.35 \\
\hline
\end{tabular}

${ }^{\dagger}$ Starter feed composition: $0 \% \mathrm{CP}$ = starter without citrus pulp; $32 \% \mathrm{CP}=$ starter containing $32 \% \mathrm{CP}$ as a replacement for corn; $64 \% \mathrm{CP}=$ starter containing $64 \% \mathrm{CP}$ as a replacement for corn.

¥Minerals and vitamins composition: Ca 16.8\%; P 4.2\%; S 2.3\%; Na 11.6\%; Cl 8.0\%; Mg 2.4; Co 38.2 ppm; Cu 343 ppm; I 30.2 ppm; Fe 578.2 ppm; Mn 1146.4 ppm; Se 15.5 ppm; Zn 1176.2 ppm; Vit. A 68,760 UI/kg; Vit. E 764 UI/kg; Vit. D 57,300 UI/kg.

${ }^{\S}$ Estimated value by NRC (2001)

Table 2. Average values of three days of evaluation score of clinical signs and physiological parameters of diarrhea calves fed concentrate containing citrus pulp replacing corn

\begin{tabular}{|c|c|c|c|c|c|c|c|c|}
\hline & \multicolumn{3}{|c|}{ Treatments $^{\dagger}$} & \multirow{2}{*}{ SEM } & \multicolumn{4}{|c|}{$\mathrm{P}<\neq$} \\
\hline & $0 \% \mathrm{CP}$ & $32 \% \mathrm{CP}$ & $64 \% \mathrm{CP}$ & & $\mathrm{T}$ & $\mathrm{D}$ & $\mathrm{H}$ & TxDxH \\
\hline $\begin{array}{l}\text { Clinical Score } \\
(0-12)\end{array}$ & 3.94 & 3.19 & 3.95 & 0.73 & 0.67 & 0.48 & 0.0003 & 0.99 \\
\hline Retal $\mathrm{T}^{\mathrm{o}} \mathrm{C}$ & 39.3 & 39.5 & 39.1 & 0.19 & 0.38 & 0.62 & $<.0001$ & 0.67 \\
\hline $\begin{array}{l}\text { Respiratory } \\
\text { rate (rpm) }\end{array}$ & 50.3 & 41.4 & 41.6 & 6.05 & 0.59 & 0.94 & $<.0001$ & 0.19 \\
\hline $\begin{array}{l}\text { Heart rate } \\
(\mathrm{bpm})\end{array}$ & 88.3 & 80.6 & 79.9 & 2.99 & 0.19 & 0.21 & $<.0001$ & 0.65 \\
\hline
\end{tabular}

${ }^{+}$Starter feed composition: $0 \% \mathrm{CP}$ = starter without citrus pulp; $32 \% \mathrm{CP}=$ starter containing $32 \% \mathrm{CP}$ as a replacement for corn; $64 \% \mathrm{CP}=$ starter containing $64 \% \mathrm{CP}$ as a replacement for corn.

${ }^{\ddagger} \mathrm{T}$ = treatment effect; $\mathrm{D}$ = day effect; $\mathrm{H}=$ Time of evaluation effect; TxDxH treatment, day and time interaction.

starter concentrate, the evaluation day or the interaction of these factors (Table 3). There was no observed effect of the starter concentrate composition on blood gas analyses, electrolyte evaluations and metabolites of animals during diarrhea cases (Table 3). However, total and D-lactate blood concentrations were higher $(\mathrm{P}<0.05)$ for calves fed with control or concentrate containing $64 \% \mathrm{CP}$, while the highest concentration of L-lactate $(\mathrm{P}<0.05)$ was observed for those fed 64\% CP (Table 3). In addition, blood pH, HCO3 and $\mathrm{K}$ blood concentrations were affected by the evaluation day $(\mathrm{P}<0.05)$, with reducing values as days pass by (Fig.3). 

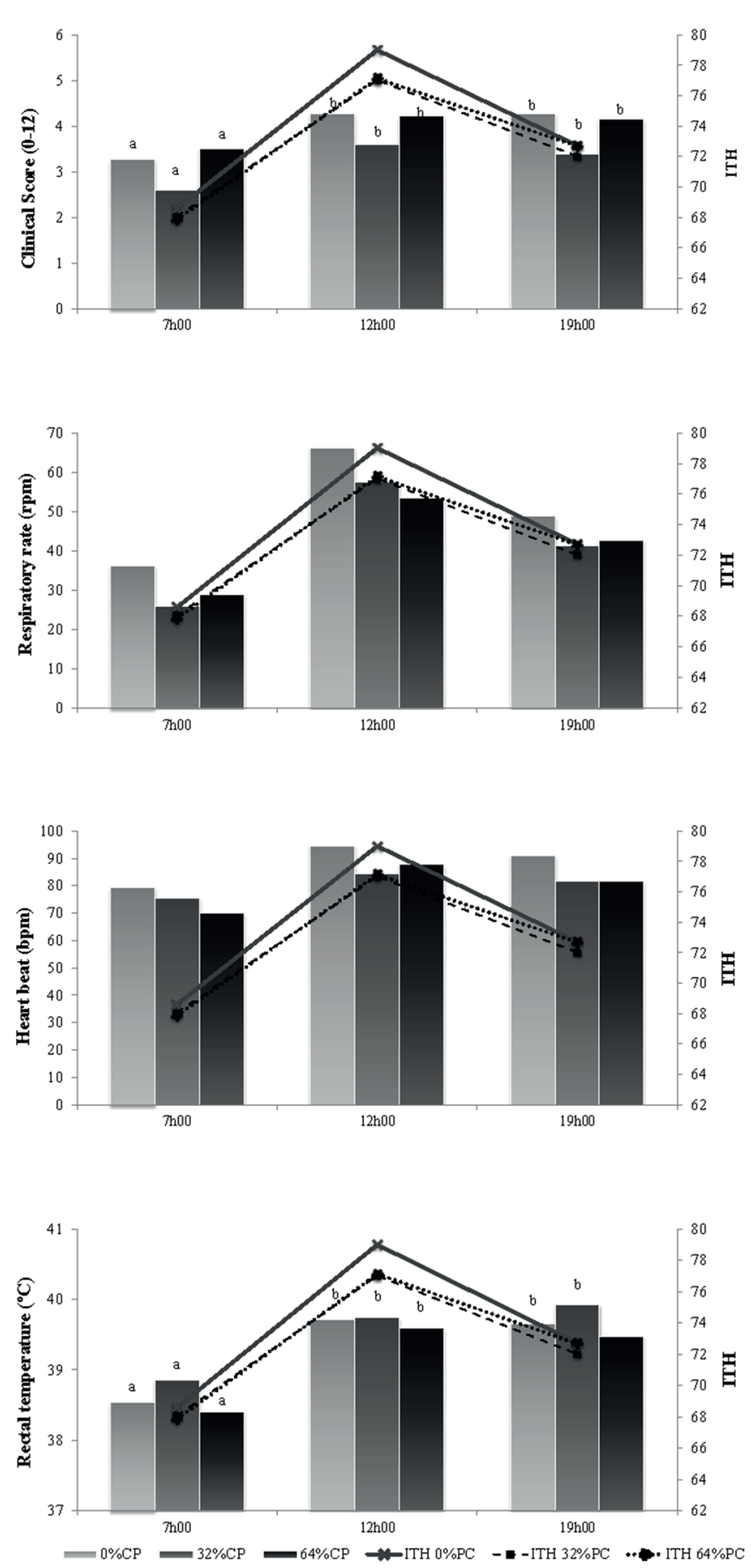

Fig.2. Clinical scores and physiological parameters of diarrheic calves fed starter feed containing citrus pulp.

\section{DISCUSSION}

Considering the average temperature, animals were in thermal comfort since the upper critical temperature for calves is $25^{\circ} \mathrm{C}$ and the lower critical temperature is $13^{\circ} \mathrm{C}$ (Davis \& Drackley 1998). However, maximum temperature were always higher which may have caused some heat stress mainly at the middle of the day, with increases in respiratory and heart beat rates as shown by Figure 2. In addition, average THI was higher than that considered adequate for dairy calves. According to Armstrong (1994), values up to 72 did not cause stress in the animal, and values from 72 to 78 represent mild stress.
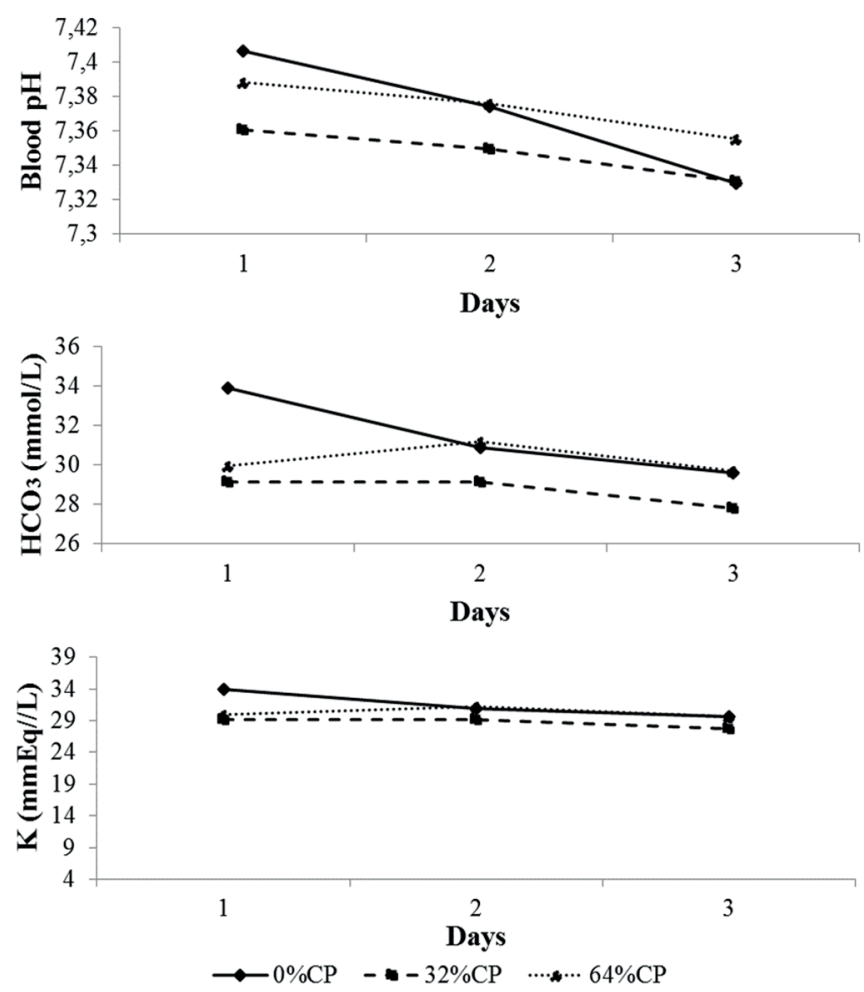

Fig.3. Effect of evaluation days on blood pH, and concentrations of HCO3 and K of diarrheic calves fed starter feed containing citrus pulp.

Table 3. Blood gas and electrolytes analysis assessment, and plasma biochemical metabolites of diarrheic calves fed concentrate containing citrus pulp replacing corn

\begin{tabular}{|c|c|c|c|c|c|c|c|}
\hline & \multicolumn{3}{|c|}{ Treatments $^{\dagger}$} & \multirow[t]{2}{*}{ SEM } & \multicolumn{3}{|c|}{$\mathrm{P}<\neq$} \\
\hline & $0 \% \mathrm{CP}$ & $32 \% \mathrm{CP}$ & $64 \%$ СР & & $\mathrm{T}$ & D & TxD \\
\hline Hematocrit (\%) & 23.8 & 24.2 & 23.7 & 2.97 & 0.99 & 0.70 & 0.82 \\
\hline $\mathrm{pH}$ & 7.37 & 7.35 & 37 & 0.03 & .73 & 0.04 & 0.83 \\
\hline $\mathrm{HCO}^{3}(\mathrm{mmol} / \mathrm{L})$ & 28.53 & 26.69 & & 13 & 69 & 05 & 0.33 \\
\hline & & 5 & & 68 & 48 & 81 & 0.69 \\
\hline & & & & & 83 & 05 & 0.24 \\
\hline & 1 & 13 & & 85 & 99 & .08 & 0.91 \\
\hline & & & & 2.81 & .95 & 0.61 & 0.41 \\
\hline & 1 & 13.2 & 11. & 0.89 & 0.37 & 0.19 & 0.29 \\
\hline & & & 4.9 & 2.53 & 0.69 & 0.08 & 0.33 \\
\hline & 8.72 & 32 & 8.45 & 1.73 & 0.99 & 0.71 & 0.45 \\
\hline & 0.052 & 0.051 & 0.070 & 0.008 & 0.23 & 0.43 & 0.39 \\
\hline & 83.51 & 87.24 & 86.11 & 6.07 & 0.92 & 0.74 & 0.79 \\
\hline Tot & 5.51 & 5.56 & 5.48 & 0.89 & 0.99 & 0.15 & 0.83 \\
\hline & 3.06 & 2.82 & 2.74 & 0.19 & 0.55 & 0.72 & 0.22 \\
\hline & 7.9 & 8.7 & 7.3 & 1.53 & 0.76 & 0.40 & 0.84 \\
\hline & $20.79^{b}$ & $16.00^{\mathrm{a}}$ & $23.78^{\mathrm{b}}$ & 1.87 & 0.03 & 0.13 & 0.15 \\
\hline & $14.71^{\mathrm{b}}$ & $9.17^{\mathrm{a}}$ & $14.36^{\mathrm{b}}$ & 0.84 & 0.001 & 0.09 & 0.24 \\
\hline L-Lactate $(\mathrm{mg} / \mathrm{dL})$ & $6.08^{\mathrm{a}}$ & $6.83^{\mathrm{a}}$ & $9.42^{\mathrm{b}}$ & 0.65 & 0.02 & 0.33 & 0.13 \\
\hline
\end{tabular}

${ }^{\dagger}$ Starter feed composition: $0 \% \mathrm{CP}=$ starter without citrus pulp; $32 \% \mathrm{CP}=$ starter containing $32 \% \mathrm{CP}$ as a replacement for corn; $64 \% \mathrm{CP}=$ starter containing $64 \% \mathrm{CP}$ as a replacement for corn.

${ }^{\ddagger} \mathrm{T}$ = treatment effect; $\mathrm{D}=$ day effect; $\mathrm{H}=$ Time of evaluation effect; TxDxH treatment, day and time interaction.

a,b, Values in the same row without a common superscript letter are significantly different $(\mathrm{P}<0.05)$. 
Replacement of corn by citrus pulp had no effect on calves' fecal scores $(\mathrm{P}>0.05)$, which were evaluated according to Larson et al. (1977), considering diarrhea when score is higher than three. However, the inclusion of $64 \% \mathrm{CP}$ in the starter resulted in scores slightly higher during the 6th and 7 th weeks of age, probably because of the pectin laxative effect. The hydrophilic nature of citrus pulp may increase peristalsis, resulting in higher fecal scores. However, Schalch et al. (2001) included up to $45 \%$ CP in the concentrate for calves and observed no effects on fecal scores. Fecal characteristics evaluation from diarrheic calves show that $58 \%$ presented a yellowish color and $33 \%$ were closed to grey; $72 \%$ had an aqueous consistency (score 3) and 28\% were fluid (score 4); $56 \%$ and $37 \%$ had a slightly and highly offensive odor, respectively.

Clinical scores were not affected by starter feed composition but were worsened during the periods when the temperature and humidity index was greater (Fig.2). On the other hand, all observed clinical scores were below 6.5 , suggesting healthy animals according to Nakagawa et al. (2007). The main symptoms that the calves with diarrhea presented with during the experimental period were a reduction in appetite, apathy, decrease in the suckling reflex, and dehydration from light to moderate. However, there was no effect of the starter concentrate composition on these measures $(\mathrm{P}>0.05)$, so the replacement of corn with byproducts did not alter the symptoms of diarrheic animals.

Considering the normal range for rectal temperature $\left(38-39.5^{\circ} \mathrm{C}\right)$, respiratory rate $(15-40 \mathrm{rpm})$, and heart beat (60 to $120 \mathrm{bpm}$ ) of dairy calves (Davis \& Drackley 1998), and the lack of effect of the starter composition on physiological parameters (Fig.2), it may be concluded that variations observed are related to environmental factors. Only measurements done at $7 \mathrm{~h} 00$ revealed average rectal temperature and respiratory rate within the normal range. Measurements done at $12 \mathrm{~h} 00$ and $19 \mathrm{~h} 00$ were higher than that (Fig.2). Heart beat rate was also higher at $12 \mathrm{~h} 00$ and $19 \mathrm{~h} 00$ than that observed in the morning, but did not exceeded normal range in any of the measurements (Fig.2). Therefore, altered physiological parameters suggest a mild heat stress with the advance of the day, confirmed by the increased THI. Heat stress may increase energy requirements even more for animals that are already dealing with diarrhea. Even though there was a time effect, there was no interaction between time of day and starter concentrate composition $(\mathrm{P}>0.05)$, corroborating that the inclusion of citrus pulp did not alter these physiological parameters in diarrheic calves.

Hematocrit values were not affected by feed starter composition, day of evaluation, or by the interaction of these two factors ( $P>0.05$; Table 3). Although calves were affected with diarrhea, hematocrit were within the reference ranges (Ramin et al. 2012), indicating that the animals did not suffer from dehydration during the first three days of diarrhea. Besides dehydration, diarrhea may cause metabolic acidosis in calves, as a response of the decreased renal perfusion (Kasari \& Naylor 1986). The homeostatic mechanisms that control the acid-basic equilibrium are essential for the animal survival and when there is disturbance, an organ dysfunction may occur, resulting in animal's death. To assess and make a diagnosis of these disorders, blood gas analysis, blood $\mathrm{pH}$, and electrolytes balance should be evaluated (Fall 2000). The average values of the 3-day evaluation of all blood gas parameters and evaluated electrolytes were not affected by starter composition $(\mathrm{P}>0.05$; Table 3). However, the evaluation day had an influence on pH $(\mathrm{P}<0.04)$, HCO3- $(\mathrm{P}<0.05)$ and potassium $(\mathrm{P}<0.05)$, with reducing values with advanced day of evaluation (Fig.3). Considering the Henderson-Hasselbach equation, the $\mathrm{pH}$ is supposed to be reduced when $\mathrm{HCO} 3$ drops, which normally occurs during diarrhea. Potassium concentrations also usually drops as a result of diarrhea. However, decreasing levels of these parameters were similar for all concentrate starter composition. Normal ranges for $\mathrm{pH}$ (7.31-7.49), PCO2 (46-56mmHg), HCO3 (22-30mEq/L) and BEecf (3-7 mmol/L) are well established by the literature (Adams et al. 1991, Nagy et al. 2006, Do Rego Leal et al. 2008, Bellino et al. 2012). By analyzing the acid-base imbalance, the disorder may be classified in metabolic or respiratory alkalosis or acidosis.

The average blood $\mathrm{pH}$ were within normal range, indicating that even though animals were with diarrhea they were not on metabolic acidosis during the first 3 days of diarrhea. Even with the observed progressive and significant decrease in blood $\mathrm{pH}(\mathrm{P}<0.04$; Table 3$)$, the lowest observed value was higher than the minimum range. It may be possible that a longer evaluation period would reveal even lower blood $\mathrm{pH}$ values, characteristic of metabolic acidosis in animals. This $\mathrm{pH}$ reduction occurs due to excessive and progressive losses of water and electrolytes ( $\mathrm{Na}+, \mathrm{Cl}-, \mathrm{K}+$ and $\mathrm{HCO}-$-) in feces during diarrhea and by the production and accumulation of lactic acid in blood (Argenzio 1985). In fact, blood $\mathrm{pH}$ drops with advancing days occurred along with the reduction on HCO3- and K+ (Fig.3). Naylor (1989) evaluated 123 diarrheic calves and concluded that metabolic acidosis or decreased blood $\mathrm{pH}$ tends to worsen as days pass by. However, a three-evaluation day was chosen to mimic practical diarrheic calves' management. No producer will wait more than 2-3 days to rehydrate and medicate dairy calves.

In all cases of acid-basic disturbance, Anion Gap, or the plasma cation-anion difference should be evaluated because it may be altered even when $\mathrm{pH}$ is normal. An increased Anion Gap means that unmeasured plasma anions, such as lactate (lactic acidosis), acetoacetate (ketoacidosis), sulfate, phosphate and urate (decreased renal perfusion) are high. Reference values of Anion Gap for Holstein bull calves with up to 1 month of age is between 8.5 to $13.5 \mathrm{mmol} / \mathrm{L}$ (Kaneto et al. 2004). Values measured during three days are within normal range and show no effect $(\mathrm{P}>0.05)$ of the starter composition, days with diarrhea, or the interaction of this two factors for anion gap (Table 3).

Base excess (BEecf) is another important parameter to diagnose acid-basic equilibrium disorders through measures of metabolic changes in the extracellular fluid (Rocco 2003). According to the literature (Nakagawa et al. 2007, Bellino et al. 2012), calves that have BEecf values from -3 to $7 \mathrm{mmol} / \mathrm{L}$ are considered normal, lower than $-10 \mathrm{mmol} / \mathrm{L}$ 
are in metabolic acidosis and lower than $-6 \mathrm{mmol} / \mathrm{L}$ are in severe acidosis. Calves presented values higher than the normal range, suggesting that even at the third day of diarrhea calves were not in acidosis.

Potassium (K) is important in the regulation of the acid balance and it's common to find pictures of hyperkalemia (serum potassium higher than $5 \mathrm{mmol} / \mathrm{L}$ ) concentration in diarrheic calves (Maach et al. 1992). However, Reece (1980) consider serum potassium concentrations from 4.4 to $7.2 \mathrm{mmol} / \mathrm{L}$ as normal, since healthy calves $1-15$ weeks old commonly present higher values. Even though calves were diarrheic, serum potassium concentrations were within normal values, and were reduced $(\mathrm{P}<0.05)$ with days with diarrhea (Table 3, Fig.3). On the other hand, sodium concentrations were near the lower limit considered as adequate for dairy calves. Along with chlorine (Cl), sodium (Na) is important function for the maintenance of the osmotic pressure, which affects water body's metabolism and the regulation of basic-acid balance. The ideal concentration of sodium and chlorine during the first three months of life of a calf is around 132-152mmol/L and 95.0 to $111 \mathrm{mmol} / \mathrm{L}$, respectively (Bouda \& Jagos 1984)). There was no concentrate composition effect for both electrolytes blood concentrations (Table 3). Calves that have diarrhea tend to lose sodium through feces and chlorine via urine, affecting serum levels of both electrolytes. Maach et al. (1992) observed sodium blood concentrations of $131.2 \mathrm{mmol} / \mathrm{L}$ and $140.0 \mathrm{mmol} / \mathrm{L}$ for diarrheic and healthy calves, respectively. The same study revealed chlorine concentrations of $95 \mathrm{mmol} / \mathrm{L}$ for diarrheic calves as compared to $103 \mathrm{mmol} / \mathrm{L}$ for healthy calves.

The plasma concentration of (BHBA) and glucose show that energy availability for diarrheic calves were not affected by starter composition, even with the progression of the diarrhea (Table 3). Average values of BHBA were lower than those observed for calves with a developing rumen, when the epithelial rumen tissue start to oxidize butyrate produced during rumen fermentation into BHBA (Quigley et al. 1991). Reduced BHBA concentrations may indicate that rumen was still in development and animals were not capable of using most of the energy provided by the starter feed. According to Toullec \& Guilloteau (1989) calves with underdeveloped rumen are not capable to digest certain feeds, which may result in metabolic disturbances such as alimentary diarrhea. In contrast, low levels of BHBA and other ketone bodies may also suggest that energy availability was adequate. When plasma glucose level declines, due to a loss of nutrients or insufficient intake because of a gastrointestinal disorder, there is an increase of circulating ketone bodies in order to increase the energy supply to tissues, a disorder so called secondary ketosis. However, BHBA concentrations (Table 3) suggest that calves had partially developed rumen and showed no signs of secondary ketosis.

According to Haga et al. (2008), the main energy source for young calves is glucose from lactose present in milk or milk replacer, however with advancing age and rumen development, glucose concentrations tend to decrease. Blood glucose values for calves vary from 80 to $120 \mathrm{mg} /$ $\mathrm{dL}$; however, diarrheic calves may have hypoglycemia due to anorexia, poor digestion and absorption and therefore reducing hepatic gluconeogenesis and increased anaerobic glycolysis. In the present study, even though calves were with diarrhea, plasma glucose levels were within normal range (Table 3).

Higher concentrations of total protein may indicate dehydration or any other disease, however values were within the normal range for dairy calves according to El-sheikh et al. (2012), and were not affected by starter composition or days with diarrhea (Table 3). Albumin represents about 50 to $65 \%$ of the total protein and is essential for maintaining osmotic pressure necessary for the proper distribution of body fluids between the intravascular and extravascular compartment (Pekcan et al. 2012). Even though animals were with diarrhea, total protein and albumin were normal (Table 3).

The concentration of plasma urea nitrogen (PUN) depends on factors such as nutrition, physiological state, and diseases such as diarrhea and kidney problems. The starter composition had no effect on PUN concentrations, as well as days with diarrhea (Table 3), with average value of $7.9 \mathrm{mg} / \mathrm{dL}$. Seifi et al. (2006) found PUN concentrations between 4.65 to $7.68 \mathrm{mg} / \mathrm{dL}$ for healthy calves, while diarrheic calves presented concentrations from $10.75 \mathrm{mg} / \mathrm{dL}$ to 28 , and of $61 \mathrm{mg} / \mathrm{dL}$ in severe cases. The adequate values observed, along with blood $\mathrm{pH}$ and electrolytes concentrations, indicates absence of dehydration and of metabolic disturbance in diarrheic animals, regardless of the starter concentrate composition.

The resulting metabolic acidosis from diarrhea in calves may be worsened due to the production and consequent increase in lactic acid concentrations (Millemann 2009). Llactate is one of the acids responsible for acidosis, and its increased concentration may occur because of dehydration or the reduced liver efficiency in sick calves (Omole et al. 2001). As well, D- lactate contributes to acidotic conditions and is associated with poorly digested feed, favoring D-lactate producing bacteria proliferation, common condition in animals with severe metabolic acidosis (Ewaschuk et al. 2004). Values considered normal for calves are between 6 to $22 \mathrm{mg} / \mathrm{dL}$ for total lactate; up to $11.8 \mathrm{mg} / \mathrm{dL}$ for L-lactate; and $3.9 \mathrm{mg} /$ dL for D-lactate (Kasari \& Naylor 1986). Trefz et al. (2012) observed L-lactate concentrations of $16 \mathrm{mg} / \mathrm{dL}$ for diarrheic calves, but concentrations high as $40 \mathrm{mg} / \mathrm{dL}$ in severe cases. According to Lorenz (2004), for animals presenting diarrhea and metabolic acidosis, the higher the concentration of D-lactate, the worse is the clinical status of the calf. Total and D-lactate were higher for calves fed starter concentrate containing 0 and $64 \% \mathrm{CP}$, although L-lactate was higher only for calves fed 64\% CP. However, while Total Lactate and L-lactate concentrations are within the limits, those observed for D-lactate are above ideal. Despite these differences, it is clear that calves were not on metabolic acidosis, however presented values close to that considered acidotic.

\section{CONCLUSIONS}

Differences in starter composition, replacing corn by citrus pulp, had no effect on diarrhea severity or metabolic changes. 
Assessments of blood gas, electrolytes and metabolites concentrations for the first three days after the beginning of diarrhea may have been a short period to have calves with high level of dehydration and metabolic acidosis.

However, since producers treat diarrheic calves much before that, citrus pulp may replace corn without any prejudice to intestinal health or metabolism of young calves.

Acknowledgements.- The authors wish to express their appreciation for the financial support provided by São Paulo Research Foundation (FAPESP).

\section{REFERENCES}

Adams R., Holland M. D., Aldridge B., Garry F.B. \& Odde K.G. 1991. Arterial blood-sample collection from the newborn calf. Vet. Res. Commun. 15:387-394.

Argenzio R.A. 1985. Patho-physiology of neonatal calf diarrhea. Vet. Clin. N. Am., Food Anim. Pract. 1:461-469.

Armstrong D.V. 1994. Symposium on Nutrition and Heat-stress Interaction with Shade and Cooling. J. Dairy Sci. 77:2044-2050.

Bampidis V.A. \& Robinson P.H. 2006. Citrus by-products as ruminant feeds: a review. Anim. Feed Sci. Technol. 128:175-217.

Bellino C., Arnaudo F., Biolatti C., Borrelli A., Gianella P., Maurella C., Zabaldano G., Cagnasso A. \& D’Angelo A. 2012. Development of a diagnostic diagram for rapid field assessment of acidosis severity in diarrheic calves. J. Am. Vet. Med. Assoc. 240:312-316.

Botteon R.C.C.M., Botteon P.T.L., Santos Junior J.C.B., Pinna M.H. \& Loss Z.G. 2008. Frequency of diarrhea in dairy calves submitted to different breeding conditions in the border of Rio de Janeiro and Minas Gerais states, Brazil. Braz. J. Vet. Res. Anim. Sci. 45:153-160.

Bouda J. \& Jagos P. 1984. Biochemical and hematological reference values in calves and their significance for health control. Acta Vet. Brno 53:137142 .

Davis C.L. \& Drackley J.K. 1998. The development, nutrition, and management of the young calf. Iowa State University Press, Ames, 339p.

Do Rego Leal M.L., Cyrillo F.C., Mori C.S., Santos Michima L.E., Nichi M., Ortolani E.L. \& Benesi F.J. 2008. Model for osmotic diarrhea in Holstein calves. Ciência Rural 38:1650-1657.

El-sheikh A.K.R., Morsy H.M.S., Abbas T.H.A. \& Abdelrazik W.M. 2012. Clinical and laboratory examinations of diarrhea and dehydration in newborn Friesian calves with special reference to therapy with hypertonic and isotonic solution. Life Sci. J., Acta Zhengzhou University Overseas Edition, 9:181-184.

Ewaschuk J.B., Naylor J.M., Palmer R., Whiting S.J. \& Zello G.A. 2004. D-lactate production and excretion in diarrheic calves. J. Vet. Intern. Med. 18:744-747.

Fall P.J. 2000. A stepwise approach to acid-base disorders: practical patient evaluation for metabolic acidosis and other conditions. Postgraduate Medicine 107:249.

Haga S., Fujimoto S., Yonezawa T., Yoshioka K., Shingu H., Kobayashi Y., Takahashi T., Otani Y., Katoh K. \& Obara Y. 2008. Changes in hepatic key enzymes of dairy calves in early weaning production systems. J. Dairy Sci. 91:3156-3164.

Harris B.J. \& Staples C.R. 1989. Selecting By-product Feedstuffs for Feeding Dairy Cattle. Cooperative Extension Service, IFAS, University of Florida, Gainesville, p.1-2.

Kaneto F.M., Coelho C.S., Leal M.L.R., Lisboa J.A.N. \& Benesi F.J. 2004. Glicemia e "anion-gap" em bezerras sadias da raça holandesa no primeiro mês de vida. Ars Vet. 20:291-298.

Kasari T.R. \& Naylor J.M. 1986. Further-studies on the clinical-features and clinicopathological findings of a syndrome of metabolic-acidosis with minimal dehydration in neonatal calves. Can. J. Vet. Res. 50:502-508.
Larson L.L., Owen F.G., Albright J.L., Appleman R.D., Lamb R.C. \& Muller L.D. 1977. Guidelines toward more uniformity in measuring and reporting calf experimental-data. J. Dairy Sci. 60:989-991.

Lorenz I. 2004. Influence of D-lactate on metabolic acidosis and on prognosis in neonatal calves with diarrhea. Journal of Veterinary Medicine. Series A. Phys. Path. Clin. Med. 51:425-428.

Maach L., Grunder H.D. \& Boujija A. 1992. Clinical and hematological investigations in newborn Holstein-Frisian calves with diarrhea in morocco. Deutsch. Tierärztl. Wochenschr. 99:133-140.

Millemann Y. 2009. Diagnosis of neonatal calf diarrhoea. Revue Med. Vet. 160:404-409.

Nagy O., Seidel H., Paulikova I., Mudron P. \& Kovac G. 2006. Use of blood gases and lactic acid analyses in diagnosis and prognosis of respiratory diseases in calves. Bull. Vet. Inst. Pulawy 50:149-152.

Nakagawa M., Suzuk K. \& Taguch K. 2007. Relationship between depression score and acid-base status in Japanese black calves with diarrhea. J. Vet. Med. Sci. 69:549-552.

Naylor J.M. 1989. A retrospective study of the relationship between clinical signs and severity of acidosis in diarrheic calves. Can. Vet. J. 30:577-580.

Nussio C.M.B., Santos F.A.P., Pires A.V., Simas J.M.C. \& Zopollatto M. 2002. Starch sources with different degradabilities and their partial replacement by citrus pulp for lactating dairy cows. Acta Scient. Animal Sci., 24:1079-1086.

Omole 0.0., Nappert G., Naylor J.M. \& Zello G.A. 2001. Both L- and D-lactate contribute to metabolic acidosis in diarrheic calves. J. Nutrition 131:2128-2131.

Pekcan M., Altintas A., Hilal K., Fidanci U.R., Uysal H., Besalti O., Serap U.A., Gulay C., Sibel B. \& Basak H. 2012. Serum biochemistry and native protein electrophoresis in diarrheic calves with arthritis. Acta Vet., Beograd, 62:261-269

Pryce J.D. 1969. A modification of barker-summerson method for determination of lactic acid. Analyst 94:1151-1152.

Quigley J.D., Caldwell L.A., Sinks G.D. \& Heitmann R.N. 1991. Changes in blood-glucose, nonesterified fatty-acids, and ketones in response to weaning and feed-intake in young calves. J. Dairy Sci. 74:250-257.

Ramin A.G., Asri-Rezaei S., Paya K., Eftekhari Z., Jelodary M., Akbari H. \& Ramin S. 2012. Evaluation of anemia in calves up to 4 months of age in Holstein dairy herds. Vet. Scan. 7(1):87-92.

Reece W.O. 1980. Acid-base-balance and selected hematologic, electrolyte, and blood chemical-variables in calves - milk-fed vs conventionally fed. Am. J. Vet. Res. 41:109-113.

Rocco J.R. 2003. Diagnóstico dos distúrbios do metabolismo ácido-base. R. Bras. Ter. Int. 15:184-192.

Schalch F.J., Schalch E., Zanetti M.A. \& Brisola M.L. 2001. Substitution of the corn grain ground by citric pulp in the early weaning of dairy calves. Braz. J. Anim. Sci. 30:280-285.

Seifi H., Mohri M., Shoorei E. \& Farzaneh N. 2006. Using heamatological and serum biochemical findings as prognostic indicators in calf diarrhea. Comp.Clin. Path. 15:143-147.

Thom E.C. 1959. The discomfort index. Weatherwise 12:57-60.

Toullec R. \& Guilloteau P. 1989. Research into the digestive physiology of the milk-fed calf. In: Nutrition And Digestive Physiology In Monogastric Farm Animals. Conference. Pudoc, Wageningen, p.37-55.

Trefz F.M., Lorch A., Feist M., Sauter-Louis C. \& Lorenz I. 2012. Metabolic acidosis in neonatal calf diarrhea: clinical findings and theoretical assessment of a simple treatment protocol. J. Vet. Intern. Med. 26:162-170.

Williams P.E.V., Fallon R.J., Innes G.M. \& Garthwaite P. 1987. Effects on food-intake, rumen development and live weight of calves of replacing barley with sugar-beet citrus pulp in a starter diet. Anim. Prod. 44:6573

Wing J.M. 1982. Citrus feedstuffs for dairy cattle. Agricultural Experiment Stations, IFAS, University of Florida, Gainesville. 17p. 